\title{
DIMENSI KEBERHASILAN PENDIDIKAN ISLAM PROGRAM TAHFIDZ AL-QUR'AN
}

\author{
Ahmad Fatah \\ STAI Pati, Jawa Tengah, Indonesia \\ fatahkudus1@gmail.com
}

\begin{abstract}
Abstrak
Pendidikan islam semakin berkembang. Hal ini ditandai dengan eksistensi Sekolah Islam, khususnya Madrasah Ibtidaiyyah yang membuka program tahfidz. Dalam penelitian ini, peneliti menganalisis (1) Bagaimana pelaksanaan pendidikan Islam di MI Tahfidz Al-Qur'an Krandon Kudus?; dan (2) Bagaimana keberhasilan pendidikan Islam di MI Tahfidz Al-Qur'an Krandon Kudus, yang di dasarkan pada tahfidz (penghafalan) Al-Qur'an?. Penelitian kualitatif ini menggunakan beberapa metode dalam memperoleh datanya. Yaitu dengan cara observasi, wawancara, dan dokumentasi. Hasil penelitian menunjukkan bahwa: (1) pelaksanaan pendidikan Islam di MI Tahfidz Al-Qur'an Krandon Kudus menggunakan beberapa metode, yaitu ceramah, diskusi, tanya jawab, demonstrasi atau eksperimen, resitasi dan drill; (2) keberhasilan pendidikan Islam di MI Tahfidz Al-Qur'an Krandon Kudus, yang di dasarkan pada tahfidz (penghafalan ) Al-Qur'an dibuktikan dengan prestasi siswa dan terwujudnya lingkungan masyarakat yang mendukung pembelajaran di pesantren dan madrasah.
\end{abstract}

Kata kunci: Keberhasilan, Tahfidz, Al-Qur'an, pendidikan, islam

\section{Abstract}


Ahmad Fatah

ANALYSIS OF THE SUCCESS DIMENSIONS OF ISLAMIC EDUCATION IN MI TAHFIDZ AL-QUR'AN KRANDON KUDUS. Islamic education always develops. It can be seen from the existence of islamic school, especially Islamic Elementary Schools (MI) which have tahfidz (learning Qur'an by heart) program. In this research, the researcher analysed (1) how is the implementation of islamic education in MI Tahfidz Al-Qur'an Krandon Kudus?; and (2) how is the success of islamic education in MI Tahfidz Al-Qur'an Krandon Kudus?. This qualitative research used some methods to get data. Those are observation, interview, and documentation. The result showed that (1) the implementation of islamic education in MI Tahfidz Al-Qur'an Krandon Kudus used some methods, like observation, discussion, asking and answering, demonstration or experiment, recitation and drill; (2) the success of islamic education in MI Tahfidz Al-Qur'an Krandon Kudus is proved by the students' achievement and the environment which supports the teaching and learning process in pesantren and islamic schools.

Keywords: Success, Tahfidz, Al-Qur'an, education, islam

\section{A. Pendahuluan}

Salah satu aspek kehidupan umat muslim di Indonesia yang benar-benar memerlukan pemikiran dan usaha terus-menerus untuk memperbaikinya, adalah bidang pendidikan. (Ali, 1971: 10). Bidang ini sangat penting untuk dipikirkan, karena dalam pengertian yangluas menyangkut upaya penyampaian, pengembangan, dan peningkatan kualitas keberagamaan di kalangan umat Islam. Keberhasilan dalam bidang tersebut, pada akhirnya akan mempengaruhi kemajuan umat Islam dalam berbagai aspek kehidupan, begitu juga sebaliknya.

Anak adalah bagian kecil dari sebuah masyarakat Islam. Sebagai individu yang pada prinsipnya memiliki akal sehat yang dapat dan harus dimanfaatkannya untuk mencari ilmu. Potensi tersebut memberi kemungkinan kepada anak mengembangkan kepribadiannya, akal pikirannya yang dilatarbelakangi kesadaran berpikir yang dimiliki oleh anak (Ulwan, 1975: ii).

Terkait perkembangan kepribadian, akal pikiran dan potensi anak yang memiliki fase-fase perkembangan tertentu memerlukan bimbingan, pengajaran, pengendalian dan kontrol dari orang tua dan pendidik. Hal ini dengan tujuan mempersiapkan perkembangan 
anak agar mampu berperan serta secara berkesinambungan dan pembangunan manusia yang berkembang terus dan mampu beramal kebajikan dalam arti berakhlak mulia selama dalam upaya mencari kebahagiaan di dunia dan akhiratnya. (Al-Jumbulati, 1994: 5) Dengan demikian pendidikan terhadap anak dipandang sebagai salah satu aspek yang memiliki peranan pokok dalam pembentukan manusia agar menjadi insan yang shaleh dan memiliki kepribadian yang utama.

Berdasarkan asumsi di atas, maka diperlukan adanya pendidikan anak yang dapat membantu menyelesaikan problem yang dihadapi masyarakat dewasa ini, yaitu masih adanya dikotomi pendidikan di Indonesia, yakni adanya sekolah-sekolah yang melahirkan manusia-manusia yang menguasai ilmu pengetahuan umum, namun kurang bahkan tidak mengetahui ilmu-ilmu agama, ataupun sebaliknya. Selain itu juga gencarnya pengaruh modernisasi dan globalisasi yang ditandai dengan kecanggihan ilmu pengetahuan dan alat teknologi informasi yang menuntut lembaga pendidikan formal untuk memberikan ilmu pengetahuan umum dan ketrampilan yang banyak dan memadai kepada anak didik sebagai bekal bagi kehidupan mereka baik sekarang dan untuk masa depan, namun agak meninggalkan kesempatan anak-anak untuk mengeyam pendidikan agama sebagai bekal di dunia dan di akhirat kelak. Maka dari itu hendaknya pendidikan dapat menyentuh seluruh aspek yang bersinggungan langsung dengan kebutuhan perkembangan individu anak, baik bekal dari ilmu agama maupun ilmu pengetahuan umum agar mereka dapat hidup dan berkembang sesuai dengan konsep ajaran Islam yang kaffah (menyeluruh).

Pendidikan yang dilaksanakan umat Islam di Indonesia salah satu jenis kelembagaannya adalah madrasah, yang madrasah itu sendiri sebagai lembaga pendidikan Islam di Indonesia. (Ziemek, 1985: 57). Madrasah telah menarik perhatian para ahli dan pakar, untuk melakukan studi dan kajian untuk mengungkap dan memahami hal ihwal dan seluk beluknya. Kajian atau tulisan sebagaimana dimaksud, antara lain dilakukan oleh Malik Fadjar dalam bukunya, Madrasah dan tantangannya, Maksum Mukhtar dalam bukunya Madrasah dan Perkembangannya. Namun demikian, bukan berarti aneka permasalahannya sudah terselesaikan secara 
tuntas dan mendalam. Masih ada juga hal-hal yang unik dan cukup menarik yang belum tersentuh oleh rangkaian kajian oleh para ahli dan pakar tersebut, diantaranya adalah madrasah Ibtidaiyah (MI) Tahfidz Al-Qur'an Kradon Kudus. MI ini adalah Madrasah Ibtidaiyah yang integrasi dengan pondok peantren tahfidz anakanak Yanbu' Al-Qur'an. Pendidikan utamanya adalah menghafal AlQur'an 30 juz dan diajarkan pula ilmu-ilmu agama seperti aqidah, ibadah, akhlak, tajwid dan bahasa Arab dasar. Di samping itu anakanak belajar di Madrasah Ibtidaiyah (MI) yang ada di lingkungan pondok pesantren yang mengajarkan ilmu pengetahuan agama dan ilmu pengetahuan umum. Sungguh unik dan menarik model madrasah Tahfidz Al-Qur'an ini dalam dunia pendidikan umat Islam di Indonesia. Kemunculan madrasah ini dirasa amat penting bagi santri anak-anak yang ingin sekolah, jadi ketika belum ada madrasah anak-anak sekolah diluar pesantren, dan itu amat memberatkan santri dan pengurus, maka atas inisiatif kyai dan pengurus didirikanlah MI untuk memudahkan santri dalam sekolah. Seiring awal kehadiran dan keberadaan madrasah Ibtidaiyah Tahfidz Al-Qur'an diharapkan kelak akan muncul generasi muda muslim yang benar-benar memahami Islam sekaligus memiliki kemampuan dan kesadaran untuk meyampaikan risalahnya di tengah masyarakat dengan bekal hafalan Al-Qur'an, ilmu pengetahuan agama dan ilmu pengetahuan umum.

Berdasarkan latar belakang masalah yang telah disebutkan, maka penulis tertarik untuk meneliti Analisis Keberhasilan pendidikan Islam di MI Tahfidz Al-Qur'an Krandon Kudus yang berbasis pada menghafal Al-Qur'an 30 juz. Maka penulis dapat memaparkan rumusan masalah adalah sebagai berikut, yaitu: (1) Bagaimana pelaksanaan pendidikan Islam di MI Tahfidz Al-Qur'an Krandon Kudus?; dan (2) Bagaimana keberhasilan pendidikan Islam di MI Tahfidz Al-Qur'an Krandon Kudus, yang di dasarkan pada tahfidz (penghafalan ) Al-Qur'an?

Secara umum, penelitian ini untuk mencari data dan informasi yang kemudian di analisis, ditata secara sistematis dalam rangka menyajikan gambaran yang semaksimal mungkin utuh tentang Madrasah Ibtidaiyah (MI) Tahfidz Al-Qur'an Krandon Kudus Tujuan tersebut dapat dirumuskan sebagai berikut: (1) Untuk menghimpun data dan menyajikan informasi tentang pelaksanaan 
pendidikan di MI Tahfidz Al-Qur'an Krandon Kudus; dan (2) Untuk menghimpun data dan menyajikan informasi tentang keberhasilan pendidikan Islam dengan input yang berkualitas yang didasarkan pada pendidikan tahfidz di MI Tahfidz Al-Qur'an Krandon Kudus.

Pendekatan yang digunakan dalam penulisan penelitian ini adalah pendekatan kualitatif, di mana penelitian ini mempunyai cirri khas yang terletak pada tujuannya, yakni mendiskripsikan kebutuhan khusus dengan memahami makna dan gejala. Dengan pengertian lain pendekatan kualitatif memusatkan perhatiannya pada prinsip-prinsip umum yang melandaskan pada perwujudan dan satuan-satuan gejala yang muncul dalam kehidupan manusia. (Suparlan, 1993: 9). Oleh karena itu sasaran penelitian ini adalah pola-pola yang berlaku dan mencolok berdasarkan atas perwujudan dan gejala-gejala yang ada pada kehidupan manusia. Jadi pendekatan ini sebagai prosedur penelitian yang menghasilkan data diskriptif berupa kata-kata tertulis atau lisan dari orang-orang dan prilaku yang dapat diamati dan diarahkan pada latar alamiah dan individu tersebut secara holistik (utuh) (Moleong, 2001: 3)

\section{B. Pembahasan}

\section{Kajian Pustaka}

Saat penulis mengadakan pelacakan literatur yang membahas madrasah, ternyata sudah cukup banyak literatur kemadrasahan baik yang bersifat normativ maupun empiris, namun literatur atau karya yang mengkaji tentang madrasah tahfidz Al-Qur'an anak-anak masih sedikit, yaitu karya yang berupa artikel atau tulisan disertasi dan tesis.

Bawani (1995) dalam disertasinya pada program pascasarjana IAIN Sunan Kalijaga Yogyakarta yang berjudul Pesantren Anak-Anak Sidayu Gresik Jawa Timur yang membahas tentang pendidikan yang diberikan pada anak balita/prasekolah mengenai membaca dan menulis Al-Qur'an dan pendidikan agama dengan system asrama baik di lingkungan pesantren maupun lingkungan masyarakatnya. Alang (2000) dalam disertasinya pada program pascasarjana IAIN Sunan Kalijaga Yogyakarta yang berjudul Anak Shaleh Telaah Pergumulan Nilai-Nilai Sosio Kultural dan Keyakinan Islam Pada 
Pesantren Modern Datok Sulaiman Palopo Sulawesi Selatan. Disertasi ini membahas upaya pembentukan anak shaleh pada pesantren modern Datok Sulaiman Palopo, penelitian ini terfokus pada pergumulan antara nilai-nilai sosio kultural yang diramu pesantren. Anak shaleh yang ada di lingkungan pesantren merupakan out put dari seluruh sistem pendidikan yang diselenggarakan di pesantren dengan pengintegrasian ke sekolah dengan suatu koordinasi. Huda (2002) dalam tesisnya pada program pascasarjana IAIN Sunan Kalijaga Yogyakarta yang berjudul Lembaga Pendidikan Dasar AlQur'an Studi atas Nggon Ngaji dan TKA-TPA. Tesis ini meneliti tentang perkembangan lembaga pendidikan Al-Qur'an di Indonesia, terutama di Jawa, namun kajian difokuskan pada lembaga yang oleh orang Jawa disebut Nggon Ngaji. Pembahasan tesisi ini bertujuan untuk mengungkap perkembangan lembaga pendidikan dasar AlQur'an tersebut, beberapa aspek pendidikannya, dan pola-pola hubungannya. Dhofir (1992: 88) mengatakan bahwa munculnya pengajian Al-Qur'an yang oleh orang Jawa disebut nggon ngaji tidak bisa dipisahkan dengan umat Islam di Jawa dan mempunyai cirri khas Jawa sehingga disebut system pendidikan orang Jawa.

Sedangkan literatur atau karya yang membahas pesantren pada umumnya cukup banyak, antara lain: Madrasah dan Tantangannya oleh Malik Fadjar, merupakan tulisan beliau yang mengupas madrasah mulai dari perkembangan madrasah sampai tantangan dan problem yang dihadapi madrasah saat ini. Madrasah dan Perkembangannya, sebuah disertasi Maksum Mukhtar yang menganalisa madrasah dan perkembangannya di Indonesia dan model madrasah di Indonesia yang diambil dari madrasah di Timur Tengah. Tahun 1986, penulis Belanda Karel A.Steenbrink dengan bukunya yang berjudul Pesantren, Madrasah dan Sekolah, Pendidikan Islam dalam Kurun Modern, yang membahas tentang institusi pesantren yang bergeser hingga madrasah sampai sekolah. Selain itu masih banyak buku lain yang judulnya bukan madrasah, namun sebagian pembahasannya berhubungan dengan madrasah yang dapat melengkapi data-data informatif historis-sosiologis dalam kajian ini. Buku-buku sejarah pendidikan maupun sejarah pendidikan Islam di Indonesia selalu memuat bahasan tentang madrasah, dan tidak sedikit karya ilmiah berupa tesis dan disertasi yang membahas tentang madrasah. 
Secara kuantitatif, buku-buku atau literatur yang membahas madrasah cukup banyak, namun diantara buku-buku yang dilacak penulis belum ada yang spesifik yang membahas tentang madrasah tahfidz anak-anak dengan ciri khas menghafal Al-Qur'an.

\section{Analisis Hasil}

Analisis hasil penelitian yang ditemukan peneliti akan dibahas secara jelas di bawah ini.

\section{a. Analisis Pelaksanaan Pendidikan Islam MI Tahfidz Al-Qur'an Krandon Kudus}

Pendidikan sebagai usaha membina dan mengembangkan aspek-aspek rohaniah dan jasmaniah harus berlangsung secara bertahap. Suatu proses yang digunakan dalam usaha kependidikan adalah proses yang terarah dan bertujuan mengarahkan anak didik (manusia) pada titik optimal kemampuannya. Sedangkan tujuan yang hendak dicapai adalah terbentuknya kepribadian yang bulat dan utuh sebagai manusia individual, sosial dan hamba Tuhan yang mengabdikan diri kepadaNya.

Salah satu bagian dari pendidikan adalah pendidikan agama yang terpenting dalam kehidupan untuk membentuk insan kamil. Agama Islam sebagai bagian dari sejumlah agama di dunia merupakan agama yang mempuyai pandangan hidup bahwa dunia adalah sesuatu yang fana dan permainan belaka. Manusia beragama akan lebih mementingkan kehidupan akhirat daripada dunia sehingga ini akan menjadikan dunia sebagai lapangan kebajikan untuk memperoleh kehidupan yang sempurna di akhirat.

Dalam proses pembelajaran, metode menjadi unsur utama dalam menigkatkan keberhasilan suatu pendidikan yaitu menerapkan beberapa metode dalam pembelajaran, yaitu:

1. Metode ceramah. Yaitu suatu cara penyampaian bahan secara lisan oleh guru dimuka kelas. Hal ini dilakukan oleh guru mata pelajaran Pendidikan Islam di MI ketika menyampaikan materi yang berupa fakta atau informasi. Misalnya menceritakan kisah-kisah nabi atau kisah-kisah orang baik.

2. Metode diskusi. Yaitu suatu cara mempelajari materi pelajaran 
dengan mendiskusikan masalah yang timbul dan saling mengadu argumentasi secara rasional dan objektif. Misal guru mengangkat sebuah tema tentang wudlu, kemudian guru meminta muridnya menjawab satu per satu apa itu wudlu dengan meminta murid lainnya menjawab dan menceritakan pengalamannya tentang wudlu. Sehingga akhirnya guru menyimpulkan tentang definisi wudlu dan tata cara yang benar. Diskusi anak tidak bisa seperti diskusi orang dewasa. Jadi peran guru masih sangat dominan.

3. Metode tanya jawab. Yaitu penyampaian pesan pengajaran dengan cara mengajukan pertanyaan-pertanyaan dan siswa memberikan jawaban atau sebaliknya siswa diberi kesempatan bertanya dan guru menjawab pertanyaan itu. Hal ini dilakukan ketika memulai pelajaran pada saat pertengahan ataupada akhir pelajaran.

4. Metode demonstrasi atau eksperimen. Yaitu suatu teknik mengajar yang dilakukan oleh guru dengan sengaja diminta atau siswa sendiri ditunjuk untuk memperlihatkan pada kelas tentang suatu proses atau cara melakukan sesuatu. Misalkan praktik shalat.

5. Metode resitasi atau pemberian tugas untuk dikerjakan di rumah. Hal ini dilakukan guru supaya siswa aktif dan memiliki rasa tanggung jawab serta untuk mengisi kekosongan waktu agar siswa dapat melakukan hal-hal yang bersifat konstruktif. Misalkan membaca buku pelajaran.

6 Metode drill. Yaitu metode dalam pengajaran dengan jalan melatih anak didik terhadap bahan pelajaran yang sudah diberikan. Misalnya menjawab soal-soal yang diberikan yang ada di buku LKS (Lembar Kerja Siswa). (Falah, 2010: 57)

Tidak semua metode diterapkan atau menggunakan satu metode saja tetapi sesuai dengan materi yang dibutuhkan. Misalnya metode ceramah digunakan ketika materi yang dijelaskan butuh penyampaian secara lisan, seperti cerita kisah nabi, menerangkan ayat-ayat $\mathrm{Al}$ Qur'an dan sebagainya. Sehingga keserasian penggunaan metode dengan materi harus diperhatikan untuk memperoleh pembelajaran yang berhasil. Sedangkan media yang digunakan 
dalam pembelajaran Pendidikan Agama Islam adalah menggunakan panduan LKS yang memuat ringkasan materi dan dilengkapi dengan evaluasi. Pemberian tugas melalui LKS juga perlu dilakukan oleh seorang guru untuk melatih daya tangkap siswa terhadap materi yang telah diajarkan, sehingga mampu mengetahui sejauh mana siswa tersebut mampu menerima dan mengerjakan tugas. Akan tetapi, disini dijumpai bentuk kreativitas guru ketika mengajar melalui pembuatan media masih sangat minim. Sehingga pembelajaran yang berlangsung kurang begitu menarik dan akhirnya keaktifan negatif seorang anak di dalam kelas mulai tampak, seperti berbicara sendiri dengan teman-temannya, ramai dan sebagainya. Disinilah guru mengalami kesulitan dalam mengajar.

Selain itu, pembelajaran Pendidikan Islam selain menggunakan buku panduan LKS yang diajarkan, juga memuat pelajaran tafsir dan Al Qur'an dengan menggunakan metode hafalan dan praktik menulis. Disamping itu, kegiatan tambahan yang dapat mendukung pembelajaran Pendidikan Agama Islam di MI ini juga terdapat kegiatan ekstrakurikuler seni baca Al Qur'an dan tadarus. Sehingga memperkuat atau menambah pengetahuan untuk pembelajaran Pendidikan Islam. Siswa pun mampu termotivasi untuk terus belajar Pendidikan Agama Islam. Penggunaan metode dalam satu mata pelajaran bisa lebih dari satu macam (bervariasi). Metode yang variatif dapat membangkitkan motivasi belajar anak didik. Dalam pemilihan dan penggunaan sebuah metode harus mempertimbangkan aspek efektifitasnya dan relevansinya dengan materi yang disampaikan. Evaluasi yang baik selalu diadakan setelah seorang guru selesai mengajarkan materi, sehingga guru mampu mengetahui seberapa besar daya tangkap siswa menyerap dan memahami materi yang diajarkan. Untuk itu, ulangan harian perlu diadakan untuk mengevaluasi hasil pembelajaran baik dari sisi guru mengajar maupun siswa dalam menerima materi. Selain itu, evaluasi tanya jawab ketika mengajar juga perlu dilakukan untuk membentuk keaktifan siswa dalam belajar, sehingga siswa tidak hanya cenderung pasif atau berbicara sendiri dengan temannya.

Dalam pembelajaran di MI ini, pelaksanaan ulangan harian telah dilakukan oleh seorang guru Pendidikan Agama Islam, ulangan harian tersebut rutin dilakukan setelah selesai mengajarkan 
materi dan tes semester yang dilakukan setiap tahunnya. Disinilah salah satu tolak ukur keberhasilan pembelajaran Pendidikan Islam dapat dilihat.

Sarana prasarana yang ada di MI ini dapat dikatakan cukup memadai. Pemafaatan sarana prasarana yang ada juga dapat digunakan dengan baik. Akan tetapi, disini dijumpai bentuk kreatifitas guru ketika mengajar melalui pembuatan media masih sangat minim. Sehingga pembelajaran yang berlangsung kurang begitu menarik dan akhirnya keaktifan seorang anak di dalam kelas mulai tampak, seperti berbicara sendiri dengan teman-temannya, ramai dan sebagainya. Disinilah guru mengalami kesulitan dalam mengajar.

Berbicara mengenai kurikulum, yang mana kurikulum ini merupakan bagian yang tidak terpisahkan dari pengajaran. Kurikulum mempunyai kedudukan sentral dalam dunia pendidikan. Saat ini kurikulum yang digunakan di MI ini adalah kurikulum KTSP (Kurikulum Tingkat Satuan Pendidikan) yaitu kurikulum operasional yang disusun dan dilaksanakan oleh masing-masing satuan usaha pendidikan. Untuk masalah pendekatan yang digunakan di Al-Qur'an Krandon Kudus ini menggunakan pendekatan CTL (Contekstual Teaching Learning) yaitu siswa dihadapkan pada fakta atau kejadian nyata dalam kehidupan yang dialami oleh siswa. Dengan kata lain bahwa seorang guru mengajarkan materi kepada siswanya tentang sesuatu yang pernah dialami dalam kehidupan, sehingga siswa terlibat langsung. Sama halnya dengan pelajaran Pendidikan Islam juga menggunakan pendekatan CTL yaitu pendekatan kepada siswa tentang kenyataan-kenyataan yang dialami siswa dalam kehidupan. Seperti dalam contoh pengadaan zakat di sekolah pada bulan Ramadhan oleh pihak sekolah dan penyembelihan hewan kurban pada saat hari raya Idul Adha. Dengan cara tersebut, siswa akan terlibat aktif dalam penerapan teori yang pada akhirnya menghasilkan karya dan bisa menerapkan teori ke dalam praktik. Sehingga siswa melaksanakan langsung tentang materi Pendidikan Agama Islam dan siswa juga dikenalkan kepada Tuhan bagaimana caranya mendekatkan diri kepada Tuhan yang bertujuan untuk meningkatkan keimanan dan ketaqwaan.

Dari mulai penggunaan metode, penggunaan media, dan penerapan kurikulum dan mengatur siswa di kelas, dimensi guru 
memegang peranan yang sangat menentukan untuk menentukan suatu keberhasilan pendidikan, karena tanpa adanya pendidik yang professional meskipun didukung oleh sarana dan media yang tercukupi, tentu keberhasilan pendidikan tidak akan maksimal, juga sebaliknya ketika guru yang profesioanal tidak didukung oleh sarana dan media yang mencukupi tentu tidaklah berhasil suatu pembelajaran. Jadi aspek-aspek yang perlu diperhatikan ketika suatu pembelajaran dapat ditentukan untuk berhasil maka yang harus dilaksnakan adalah dimensi pendidik yang profesional, sarana prasarana dan media yang mencukupi, dan tentunya yang tidak kalah penting adalah input siswa yang cukup baik, dengan begitu keberhasilan pembelajaran pendidikan agama Islam akan bisa diraih dan berhasil.

\section{b. Analisis Keberhasilan Pendidikan Islam di MI Tahfidz Al-Qur'an Krandon Kudus}

Keberhasilan adalah sesuatu yang menunjukkan taraf tercapainya suatu tujuan. Adanya kesesuaian antara orang yang melaksanakan tugas dengan sasaran yang dituju. Dalam hal ini adalah bagaimana proses pembelajaran Pendidikan Islam dapat berhasil dan dapat menghantarkan peserta didik mencapai tujuannya.

Mengajar yang berhasil dan efektif adalah proses pembelajaran yang mampu memberikan nilai tambah atau informasi baru bagi siswa. Dengan proses pembelajaran siswa benar-benar memperoleh tambahan informasi baru dari guru. Seorang guru ketika mengajar harus benar-benar memperoleh memiliki kemampuan untuk menjelaskan atau memberikan materi yang bermakna dan baru bagi siswa, sehingga siswa dalam mengikuti pembelajaran dari guru akan semakin menyenangkan (Mukhit, 2009: 32)

Pembelajaran yang efektif menuntut keterlibatan peserta didik secara aktif karena mereka merupakan pusat kegiatan pembelajaran. Peserta didik harus didorong untuk menafsirkan informasi yang disajikan oleh guru sampai informasi tersebut dapat diterima akal sehat. Pembelajaran yang berhasil perlu ditunjang suasana dan lingkungan belajar yang memadai. Oleh karena itu, guru harus mampu mengelola tempat belajar dengan baik, mengelola peserta didik, kegiatan pembelajaran, isi pembelajaran dan sumber belajar. 
Penyampaian ajaran agama dapat diperoleh dengan jalan mempelajari pendidikan agama itu sendiri. Pengaruh agama itu karena yang dimaksud disini agama Islam, maka dengan ajaran agama dapat diperoleh dengan jalan mempelajari pendidikan agama itu sendiri. Pengaruh agama itu karena yang dimaksud disini adalah agama Islam, maka dengan sendirinya membina dua sektor pada diri seseorang. Pertama, membina budinya. Kedua, membina otaknya. Sebab orang yang beragama menurut ajaran agama Islam adalah orang yang mementingkan rohaniah.

Berbicara mengenai keberhasilan suatu pendidikan, tidak terlepas juga dari benak pikiran mengenai kualitas pendidik yang ada di sekolahan. Suatu sekolahan dikatakan termasuk dalam kategori baik apabila kualitas pendidiknya juga mampu diandalkan. Pendidik menjadi faktor utama dalam proses pembelajaran karena sumber ilmu yang diperoleh oleh peserta didik berasal dari gurunya. Melihat realita yang ada saat ini, keadan para guru di suatu sekolahan berlomba-lomba menimba ilmunya ke jenjang yang lebih tinggi untuk meningkatkan kualitas mutu pendidiknya.

Jika dilihat dari peran dan tanggungjawab guru dalam mewujudkan keberhasilan pendidikan di MI, guru memiliki tanggung jawab yang sangat besar. Peran guru untuk mewujudkan keberhasilan siswa dalam belajar berkisar $90 \%$ sedangkan siswa hanya 10\%. Hal ini menunjukkan peran guru sangat menentukan karakteristik dan kemampuan siswa dalam memahami materi pelajaran. Jika gurunya redah motivasi mengajar dan sempit wawasan pengetahuannya, maka siswa pun akan rendah motivasi belajarnya dan sempit wawasan pengetahuannya. (Mukhit, 2009: 146)

Untuk kualitas pendidik yang ada di MI ini, diungkapkan sekitar $80 \%$ pendidiknya adalah lulusan sarjana S1, dapat dilihat dari realita data tersebut, pendidik yang ada di sekolahan tersebut menunjukkan ketelitian pemilihan seorang pendidik di sekolahan tersebut sangat diperhatikan. Kualitas seorang pendidik di dalam sekolahan tersebut, juga mencerminkan kualitas output dari sekolah tersebut. Sehingga pemilihan seorang pendidik di sekolahan tersebut juga di seleksi dengan teliti.

Suatu pendidikan tidak dikatakan berhasil apabila sarana 
dan prasarananya masih belum terpenuhi. Keadaan suatu sarana dan prasarana juga menjadi unsur yang tidak dapat lepas ketika berbicara masalah efektivitas. Sarana dan prasarana yang mendukung, mampu menciptakan suatu pembelajaran yang efektif dan efisien. Sehingga masalah tersebut, perlu diperhatikan lebih teliti. Dalam sekolahan ini sarana dan prasaranya memadai, bangku tiap kelas yang mencukupi, kipas angin di dalam kelas, toilet yang bersih, laboratorium, musholla yang nyaman, perpustakaan yang mencukupi, bangunan gedung yang presentatif, alat olahraga yang mencukupi dan sebagainya.

Sesuatu yang dapat dikatakan berhasil, pasti lah membawa dampak yang ditimbulkannya. Dalam hal ini yang dimaksud adalah masalah prestasi yang diperoleh yang ada kaitan eratnya denga pembelajaran Pendidikan Islam. Sesuatu dapat dikatakan berhasil, pasti menimbulkan suatu hasil pula, utamanya dari para peserta didiknya itu sendiri.

Dalam pelaksanaan pendidikan Islam di MI Tahfidz AlQur'an Krandon Kudus sudah dinyatakan bahwa kualitas peserta didik dalam arti kemampuan dasar dan kecerdasan peserta didik selalu ditonjolkan dan diprioritaskan. Ketika kualitas peserta didik menjadi taruhannya dan dibantu oleh guru-guru yang professional dan yang berkompeten serta didukung dengan sarana prasarana yang memadai, menurut penulis untuk mencetak output yang baik dan berkualitas tidaklah sulit. Hal ini ketika penulis amati dan perhatikan bahwa siswa belajar baik belajar menghafal Al-Qur'an di pesantren dan belajar di madrasah, bukan karena dipaksa oleh pengurus dan guru, namun mereka belajar dengan penuh kesadaran bahwa mereka menyadari berada di dalam pesantren yang bisa dikategorikan sebagai "penjara” yang mengikat mereka, agar mereka berhasil dalam pendidikannya, baik pendidikan di pesantren dan pendidikan di madrasah. Meskipun mereka bagaikan terkungkung di "penjara" namun mereka tidak menyerah dan putus asa begitu saja dengan keadaan, justru karena mereka seperti dikekang, jiwa dan ekspresi kreatifitasnya muncul, mereka terasa lebih mandiri dan berjiwa keras dalam menghadapi masalah, sehingga dengan begitu mereka terkesan mudah dalam menghadapi semua permasalahan yang ada dalam diri mereka, yaitu menghafal Al-Qur'an dan belajar di madrasah. 
Berdasarkan penelitian di lapangan, mereka ketika belajar di madrasah terasa lebih mudah dan ringan, hal ini dibuktikan dengan nilai prestasi yang di raport yang nilai-niliainya rata-rata cukup tinggi, bahkan untuk kelas VI, nilai preatasinya dipandang tinggi, karena nilai mereka hampir sejajar dengan SD-SD favorit yang ada di kota Kudus.

Untuk se desa Krandon, MI tahfidz Al-Qur'an Krandon Kudus dibilang nomer satu dan mengalahkan madrasah dan sekolah yang ada di sekelilingnya, namun untuk se Kabupaten Kudus, harus bersaing dengan SD dan MI yang favorit, misal SDN Demaan, MI Muhammadiyah dan lainnya. Jadi kualitas pendidikan terutama pendidikan Islam yang dikemas dalam pendidikan pesantren dengan menghafal Al-Qur'an dan belajar agama Islam di MI dapat diukur dari prestasi nilai siswa.

Dalam kaitan ini, hasil prestasi yang diperoleh MI Tahfidz Al-Qur'an Krandon Kudus yang erat kaitannya setelah adanya pembelajaran Pendidikan Islam adalah lomba MAPSI atau mata pelajaran PAI tingkat kabupaten, lomba Pildacil, lomba rebana, lomba kaligrafi, lomba MTQ dan tartil yang selalu meraih gelar juara meskipun tidak juara satu.

Dari hasil tersebut dapat dilihat juga bahwa madrasah tersebut telah mampu mengembangkan bentuk keberhasilan pembelajaran Pendidikan Islam yang ada. Apabila pembelajaran Pendidikan Islam yang ada tidak berjalan efektif, maka tidak akan diperolehnya prestasi yang membanggakan semacam itu dan hasil output yang mampu diakui dan diterima oleh masyarakat dengan baik. Itu menandakan juga bahwa kualitas peserta didiknya mampu menerima dan mengimplementasikan ilmu yang diperolehnya khususnya mengenai materi Pendidikan Islam yang telah diajarkan baik ketika terjun dalam masyarakat maupun dalam kehidupannya.

Kualitas pendidikan Islam di MI Tahfidz Al-Qur'an Krandon Kudus, bisa dikukur dari keberhasilan mereka dalam menyesuaikan dengan lingkungan masyarakar sekitar, sehingga lingkungan masyarakat sekitar bisa dibentuk sebagai masyarakat yang agamis yang mencintai Al-Qur'an, hal ini berkat membaurnya mereka kepada masyarakat terutama pada anak-anak kecil yang belum dewasa untuk 
diajak bermain dan belajar bersama. Dengan demikian keberhasilan pendidikan Islam yang ada di MI tersebut diukur dari prestasi siswa dan membentuk lingkungan masyarakat yang mendukung pembelajaran di pesantren dan di madrasah.

\section{c. Faktor Pendukung Keberhasilan Pendidikan Islam di MI Tahfidz Al-Qur'an Krandon Kudus}

Untuk mencapai suatu keberhasilan pendidikan tentunya dibutuhkan pendukung yang cukup memadai untuk meraih keberhasilan tesebut, namun keberhasilan itu juga menemui hambatan dan kendala.

Kendala dalam suatu proses pembelajaran pasti ditemukan oleh setiap guru yang mengajar. Kendala dalam pembelajaran Pendidikan Islam adalah suatu kesulitan dalam bentuk yang nyata dalam kemahiran dan penggunaan kemampuan mendengarkan, memahami materi dan dalam mempraktikkan serta mengajarkan pendidikan Islam yang dapat mudah dipahami dan diterima oleh siswa.

Sejumlah data yang penulis terima dari informan baik yang penulis terima lewat observasi dan wawancara dengan kepala MI dan guru mata pelajaran Pendidikan Islam dalam proses pembelajaran Pendidikan Islam di MI ini, penulis dapat memaparkan hasil penelitian yang telah penulis lakukan terhadap para siswa dan guru mata pelajaran Pendidikan Islam mengenai kendala yang dihadapi dalam proses belajar mengajar. Dalam analisis ini, penulis memfokuskan kendala yang dihadapi oleh para siswa dan dalam aspek media pembelajaran yang dilaksanakan oleh gurunya. Sedangkan faktor pendukungnya adalah dilihat dari dua sisi yaitu internal dan eksternal,:

1) Faktor Internal

Faktor internal adalah faktor yang datang dari dalam diri sendiri. Faktor internal mempunyai peran yang sangat penting dalam menentukan keberhasilan siswa dalam belajar. Keadaan faktor internal yang baik akan dapat membantu keberhasilan dalam belajar. Akan tetapi sebaliknya, jika keadaan faktor internal kurang mendukung akan menghambat keberhasilan siswa dalam belajar. 
Berdasarkan hasil observasi dan wawancara kepada kepada guru pendidikan Islam dapat penulis simpulkan bahwa faktor-faktor internal yang menjadi dukungan siswa dalam belajar Pendidikan Islam adalah:

1. Faktor intelegensi

Intelegensi pada umumnya dapat diartikan sebagai kemampuan psiko-fisik untuk mereaksi rangsangan atau menyesuaikan diri dengan lingkungannya dengan cara yang tepat. Jadi intelegensi sebenarnya buka persoalan kualitas otak saja, melainkan juga kualitas organ-organ tubuh lainnya. Akan tetapi memang harus diakui bahwa peran otak dalam hubungannya dengan intelegensi manusia lebih menonjol daripada peran organ tubuh lainnya, lantaran otak merupakan sistem kontrol seluruh aktivitas manusia. (Syah, 1995: 133)

Melihat semacam itu, sebagai seorang guru yang profesional, harus mampu memahami keadaan anak didiknya antara siswa yang positif dan siswa yang negatif untuk memperlakukan sesuai dengan keadilan. Akan tetapi rasanya sulit jika sikap adil diterapkan antara siswa yang positif dengan siswa yang negatif saling bercampur dalam satu kelas. Sehingga diperlukan suatu perhatian khusus bagi siswa yang negatif tanpa mengindahkan juga perhatian untuk siswa yang positif agar tidak terjadi kecemburuan sosial.

Kecerdasan yang dimaksud disini, seorang guru memberikan materi yang sesuai dengan umur dan kemampuan siswa dalam menerima materi yang diikuti oleh perkembangan jiwa seseorang. Dalam hal ini, antara kecerdasan dan umur mempunyai hubungan yang erat. Semakin meningkat umur seseorang semakin dewasa pula cara berfikirnya.

KetikakecerdasaniniditerapkandiMITahfidzAl-Qur'an Krandon Kudus, maka dibilang bahwa tingkat kecerdasan siswa dianggap rata-rata cukup tinggi, karena mereka masuk melalui seleksi yang amat ketat dari seluruh daerah yang ada di Indonesia, khususnya Jawa dan Jawa Tengah., jadi intelegensi atau kecerdasan siswa merupakan factor pendukung keberhasilan pendidikan Islam, dengan begitu guru tinggal 
memberikan bimbingan dan motivasi dan sebagai fasilitator untuk menghantarkan siswa ke jenjang keberhasilan dalam pendidikan khsusunya pendidikan Islam.

2. Sikap siswa

Sikap adalah gejala internal yang berdimensi efektif berupa kecenderungan untuk mereaksi atau merespon (response tendency) dengan cara yang relatif tetap terhadap objek orang, barang dan sebagainya baik secara positif maupun negatif. (Syah: 135)

Dari hasil observasi, penulis dapat melihat bahwa pada waktu kegiatan proses pembelajaran sebagian siswa cukup memperhatikan materi yang diajarkan oleh guru, namun ada juga sedikit siswa yang kurang memperhatikan, hal ini disebabkan karena kurang adanya perhatian guru pada siswa tersebut, mungkin disebabkan karena belum dijenguk oleh orang tua, atau juga kurang sehat badannya.

Untukmengatasiadanyakemungkinanmunculnyasikap negatif, seorang guru perlu menunjukkan sikap positif terhadap dirinya sendiri dan mata pelajaran yang diampunya serta mampu meyakinkan pada para siswa akan manfaat bidang studi tersebut bagi kehidupan mereka. Sehingga setelah siswa mampu memahami hal tersebut, nantinya diharapkan sikap para siswa berangsur-angsur menjadi baik ketika proses belajar mengajar berlangsung.

\section{Bakat Siswa}

Secara umum, bakat adalah kemampuan potensial yang dimiliki seseorang untuk mencapai keberhasilan pada masa yang akan datang. Dengan demikian, sebetulnya setiap orang pasti memiliki bakat dalam arti berpotensi untuk mencapai prestasi sampai ke tingkat tertentu sesuai dengan kapasitas masing-masing. (Syah, 1995: 135)

Pemaksaan kehendak terhadap seorang siswa dan juga ketidaksadaran siswa terhadap bakatnya sendiri dan memilih sesuatu yang bukan menjadi bakatnya, akan berpengaruh besar terhadap prestasi belajarnya. 
UntukdiMITahfidzAl-Qur'an KrandonKudus, banyak ditemukan bakat yang tersimpan di benak mereka, misalnya bakat melukis, menulis khot dengan bagus, bakat olah raga, misalnya sepak bola, bulu tangkis dan sebagainya, namun bakat yang menunjang untuk pendidikan mereka adalah bakat pidato, bakat beridskusi atau berdebat, dan bakat membaca dengan lagu yang baik.

4. Minat

Minat berartikecenderungandankegairahanyangtinggi atau keinginan besar terhadap sesuatu. Adanya beberapa siswa yang kurang berminat belajar Pendidikan Islam karena menganggap pelajaran Pendidikan Islam tergolong pelajaran yang sulit yang mana di dalamnya ada hafalan dan pemahaman isinya.

Dari hasil observasi, penulis memang menemukan sebagian siswa yang mengaku sedikit kesulitan dalam menghafal surat-surat pendek beserta artinya. Disinilah peran guru harus mampu membangkitkan minat siswa untuk mengetahui pengetahuan yang terkandung dalam bidang studinya untuk menumbuhkan minat belajarnya.

\section{Motivasi siswa}

Motivasi merupakan keadaan internal organisme baik manusia ataupun hewan yang mendorong untuk berbuat sesuatu. Ada tidaknya motivasi dalam diri siswa, mampu mempengaruhi kemampuan intelektual siswa dalam belajarnya. Untuk menumbuhkan motivasi bagi siswa, diperlukan adanya motivasi intrinsik yang meliputi perasaan menyenangi materi dan kebutuhannya terhadap materi tersebut. Sedangkan motivasi ekstrinsik meliputi pujian, hadiah, suri tauladan guru serta orang tua dan sebagainya.

6. Media Pembelajaran

Media pembelajaran merupakan salah satu alat bantu dalam mengajar yang dapat menentukan keberhasilan pembelajaran. Adanya media, membantu pemahaman siswa dalam menangkap materi dengan cepat. Materi Pendidikan Islam di MI ini juga memerlukan adanya media dalam proses 
Dimensi Keberhasilan Pendidikan Islam Program Tahfidz Al-Qur’an

pembelajaran. Dari hasil wawancara dengan guru mata pelajaran Pendidikan Islam, memang ditemukan salah satu kendala di dalamnya, yakni masalah media pembelajaran. Guru Pendidikan Islam yang ada untuk saat ini masih kurangnya penggunaan dalam memanfaaatkan media untuk proses pembelajaran, karena seorang guru tersebut harus mampu membuat media itu sendiri, sehingga seorang guru disini harus dituntu kreatif sendiri dalam pembuatan media pembelajaran yang diampunya. Dalam maslah ini tentu kiranya ada program untuk pemberdayaan guru guru untuk lebih mahir mengajar dan menerapkan media khususnya kompoter kepada peserta didik, dengan mengikuti pelatihanpelatihan baik yang dilaksanakan oleh sekolah maupun diluar sekolah, ataupun juga mengikuti kursus-kursus computer, sehingga dengan begitu guru senantiasa lebih akran dan mudah menggunakan computer sebagai media pembelajaran yang penting.

b. Faktor eksternal

Faktor eksternal anak didik meliputi semua situasi dan kondisi lingkungan sekitar yang tidak mendukung aktivitas belajar anak didik. Faktor lingkungan ini meliputi:

1) Lingkungan keluarga: dukungan keluarga pada anak, terpenuhinya biaya pendiidan anak, perhatian dan motivasi orang tua pada anak.

2) Lingkungan perkampungan atau masyarakat: wilayah perkampungan yang mendukung pembelajaran anakmerupakan lingkungan yang bagus dan kondusif bagi anak, apalagi lingkungan masyarakat yang sangat mendukung adanya pelaksanaan pembelajaran yang ada di pesantren dan di madrasah, sehingga lingkungan perkampungan dan masyarakat merupakan faktor yang penting untuk mendukung pelaksanaan pendidikan.

3) Lingkungan madrasah: kondisi dan letak gedung madrasah yang bagus dan representatife yang jauh dari keramaian dan kebisingan, kondisi guru dan alat-alat belajar yang berkualitas baik merupakan faktor yang penting untuk mendukung keberhasilan pendidikan Islam. 
Ahmad Fatah

\section{C.Simpulan}

Berdasarkan penelitian yang telah dilakukan, hasilnya menunjukkan bahwa: (1) Pelaksanaan pendidikan Islam di MI Tahfidz Al-Qur'an Krandon Kudus menggunakan beberapa metode, yaitu ceramah, diskusi, tanya jawab, demonstrasi atau eksperimen, resitasi dan drill; dan (2) Keberhasilan pendidikan Islam di MI Tahfidz Al-Qur'an Krandon Kudus, yang di dasarkan pada tahfidz (penghafalan ) Al-Qur'an dibuktikan dengan prestasi siswa dan terwujudnya lingkungan masyarakat yang mendukung pembelajaran di pesantren dan madrasah. 


\section{DAFTAR PUSTAKA}

Al-Ainaini, Ali Khalil Abu. 1980. Falsafah al-Tarbiyah al-Islamiyah fi Al-Qur'an al-Karim. Mesir: Dar al-Fikr al-Arabi.

Al-Asfahani, Al-Raghib. Mu'jam Mufradat Alfadz Al-Qur'an, Dar alKatib al-Arabi.

Ali, A. Mukti. 1971. Pelbagai Persoalan Islam di Indonesia Dewasa ini. Yogyakarta: Yayasan Nida, Cet. II.

Al-Jumbulati, Ali. 1994. Perbandingan Pendidikan Islam. Terj. H.M. Arifin. Jakarta: Rineka Cipta.

Departemen Agama. 1995. Al-Qur'an dan Terjemahnya. Semarang: Toha Putra.

Dhofir. 1992. Sekolah Al-Qur'an di Jawa. Jurnal Ulum Al-Qur'an, Vol. III, No. 4.

Djamarah, Syaiful Bahri. 2002. Psikologi Belajar. Jakarta: Rineka Cipta.

Falah, Ahmad. 2010. Aspek-Aspek Pendidikan Islam. Yogyakarta: Ide Press.

Hajar, Ibnu. 1996. Dasar-dasar Metodologi Pembahasan Kuantitaif dalam Pendidikan. Jakarta: Raja Grafindo Persada.

Hasan, Chalidjah. 1994. Dimensi-Dimensi Pendidikan Islam. Surabaya: al-Ikhlas.

Komariah, Aan dan Cepi Triatna. 2005. Visionary Leadership Menuju Sekolah Efektif. Jakarta: Bumi Aksara,.

Madjid, Nurcholis. 1987. Islam, Kemodernan dan Keindonesiaan. Bandung: Mizan, Cet I.

Moleong, Lexy J. 2001. Metodologi Penelitian Kualitatif. Bandung: Remaja Rosda Karya, Cet. XIV.

Muhadjir, Noeng. 1998. Metodologi Penelitian Kualitatif. Yogyakarta: Rake Sarasin, Cet. VIII.

Muhaimin. 2001. Paradigma Pendidikan Islam: Upaya Mengefektifkan Pendidikan Agama Islam di Sekolah. Bandung: Remaja Rosdakarya. 
Ahmad Fatah

Mukhit, Saekhan. 2009. Pembelajaran Kontekstual. Semarang: Rasail.

Rahardjo, Dawam. 1996. Ensiklopedi Al-Qur'an Tafsir Sosial Berdasarkan Konsep-Konsep Kunci. Jakarta: Paramadina.

Sanjaya, Wina. 2009. Kurikulum dan Pembelajaran Teori dan Praktik Pengembangan Kurikulum Tingkat Satuan Pendidikan. Jakarta: Kencana Prenada Media Group.

Sukmadinata, Nana Syaodih. 2009. Pengembangan Kurikulum Teori dan Praktik. Bandung: Remaja Rosda Karya.

Suparlan, Parsudi. 1993. Pengantar Metode Penelitian Pendekatan Kualitatif. Majalah Media Edisi 14 tahun III. Semarang: Fakultas Tarbiyah IAIN Walisongo.

Syah, Muhibbin. 1995. Psikologi Pendidikan dengan Pendekatan Baru. Bandung: Remaja Rosakarya.

Ulwan, Abdullah Nasih. 1975. Tarbiyatul Aulad fi al-Islam, Beirut: Dar as-Salam.

Ziemek, Manfred. 1986. Pesantren dalam Perubahan Sosial. Jakarta: P3M, Cet. I. 